\title{
THE SUB CHRONIC TOXIC EFFECT OF VOODOO EXTRACT ON THE CENTRAL NERVOUS SYSTEM IN ADULT MALE ALBINO RATS
}

\author{
Ghada N. Mansour, M.D. ${ }^{1}$, Mohamad Z. M. Hassan M.D. ${ }^{1}$, Ola Elsayed Nafea M.D. ${ }^{1}$, \& \\ Maha Zayed Mohamed M.D. ${ }^{2}$ \\ ${ }^{1}$ Forensic medicine \& Clinical Toxicology Department, Faculty of medicine, Zagazig \\ University. \\ ${ }^{2}$ Histology Department, Faculty of Medicine, Zagazg University.
}

Corresponding Author: Ghada N. Mansour.

\section{ABSTRACT}

Introduction: Voodoo is a mixture of herbs and spices that are sprayed with a synthetic compound that mimics the effects of Cannabis. The widespread over-the-counter availability of these products made these compounds the $2^{\text {nd }}$ most common frequently used recreational drug after marijuana in teenagers and young adults. This study aimed to investigate the sub chronic toxic effects of Voodoo (Voodoo abuse) on the central nervous system (CNS) in adult male albino rats.

Methodology: thirty adult male albino rats were divided into three equal groups; negative control group, positive control group, and Voodoo extract treated group. Behavioral tests, neurotransmitter concentration in brain tissues and histopathological examination of brain tissues were performed.

Results: general activity changes, significant decrease in food intake, feces formation and weight gain were reported between control and Voodoo treated group. The behavioral Y maze test revealed significant inhibition of the spontaneous alternation while, locomotor activity and rotarod test revealed significant inhibition of the neuromuscular coordinative function. The neurotransmitters (serotonin, dopamine, adrenaline and noradrenaline) assaying in the brain tissues of Voodoo treated group revealed significant decrease. These neurological changes were supported by the histopathological findings in the form of shrunken cells with dense nuclei and vacuolated cytoplasm in addition to the positive cytoplasmic immunoreaction for caspase -3 in the brain tissues.

Conclusion: Voodoo extract was found to have a functional and structural deleterious CNS effect with sub chronic exposure in adult male albino rats.

Key words: Voodoo, synthetic cannabinoids, neurotransmitters.

INTRODUCTION

Cannabis is the most commonly abused drug in the world among different age groups (Tims et al., 2002) especially teenagers and young adults (Guxens et al., 2007). In Egypt, Cannabis abuse is a serious problem as it may lead to social problems, decreased work productivity and car accidents (Yassa et al., 2010).

In the past few years, synthetic cannabinoids' (SCBs) were marketed as over the counter drugs of abuse in Europe and the United States. They were available online and in small shops (Vardakou et al., 2010) and were supposed to exert the same pharmacological properties as $\triangle 9$-THC (Kearney-Ramos et al.,2014). Synthetic cannabinoids became the 2nd most frequently used drugs after marijuana in teenagers and young adults this is because of its widespread overthe-counter availability and the perception that they are safe to use (Vandrey et al., 2012 and Johnston et al., 2011). The primary psychoactive component of marijuana is $\Delta-9$ tetrahydrocannabinol $(\Delta-9-\mathrm{THC})$ which induces its effect through stimulation of cannabinoid receptors (CB1) that are distributed primarily in the central 
nervous system (CNS) (Svízenská et al., 2008). They are potent CB1-receptor agonists producing; anxiety (Schneir et al., 2011), enhancement of psychosis (Every-Palmer, 2010) and tolerance (Zimmermann et al., 2009) which in turn exerts a substantial health risk to the vulnerable populations. However, there is a lack of information about the possible effects of long-term use of SCBs (Kevin et al., 2017). Voodoo is a mixture of herbs and spices that are sprayed with SCBs, it is marketed as an herbal incense that has the same effects of Cannabis (Abbas et al.,2017). The Egyptian Ministry of Health considered Voodoo as a highly hazardous addicting substance and listed it in schedule (1) and warned traffickers and users that they are now under criminal penalties (Egypt drug regulatory authority, 2014).

\section{AIM OF THE WORK}

The aim of this study was to examine the sub chronic neurotoxicity of Voodoo (Voodoo abuse) in adult male albino rats through evaluation of the behavioral and locomotor activity tests, neurotransmitters concentration in brain tissue in addition to the histopathological and immune-histochemical examination of the brain tissue.

\section{PATIENTS AND METHODS}

\section{Preparation of the Voodoo extract:}

Voodoo sachets were used after permission from the Ministry of Justice for experimental use. Voodoo extract was prepared by adding equal mixture of diethyl ether and light petroleum (40-60) to the crushed herbal matter giving green residue (Obata and Ishikawa, 1960).

\section{Experimental animals:}

Thirty male albino rats (12 weeks old and weighed between 120 and 140 $\mathrm{gm}$ at the beginning of the study) were obtained from the animal house, Faculty of Veterinary Medicine, Zagazig
University. Rats were housed in groups in clean suitable cages (five rats per cage). Standard rodent's food was available ad libitum. Rats were left to acclimatize to the experimental conditions for 1 week before commencing the experiment. The study design was Approved from Ethical Committee for Research, Faculty of Medicine, Zagazig University.

\section{Study design:}

Rats were randomly divided into three main groups (10 rats each) as follow:

- Negative (-ve) control group: rats of this group received regular diet and water without treatment.

- positive (+ve) control group: rats of this group were given $0.5 \mathrm{ml}$ of dimethyl sulfoxide (the vehicle used to dissolve the extract) by gastric tube daily for 28 days.

- Voodoo extract treated group: According to Chopra et al., 2000 rats of this group were given dose of Voodoo extract equal to $1 / 10$ of the $\mathrm{LD}_{\mathbf{5 0}}$ (133.4 $\mathrm{mg} / \mathrm{kg})($ Gad \& Weil, 1989 and Abass et al., 2017) dissolved in $0.5 \mathrm{ml}$ of dimethyl sulfoxide daily for 28 (4 weeks) days which is equal to about 2.6 years of chronic daily use in human beings (Huestis, M. (2002).

\section{Behavioral tests:}

It was done before the start of treatment (baseline), and then was examined twice weekly for 28 days in quiet room $1 \mathrm{~h}$ after treatment.

$$
\text { - Y maze test: }
$$

Spontaneous alternation behavior was recorded during a 5-min session in a Y-maze in order to assess the spatial working memory capacity (Yamada et al. 1996). The percent alternation was calculated [defined as the total number of alternations/ total number of triads (total entries - 2)] x 100 (Faizi et al. 2012).

4. Locomotor activity test:

It was done before the start of treatment (baseline), and then was 
examined twice weekly for 28 days in quiet room $1 \mathrm{~h}$ after drug intake.

\section{- Rotaroad test:}

The coordinative function changes were evaluated by this test which was conducted according to the method of Dunham and Miya (1957). Falling from the test apparatus within $2 \mathrm{~min}$ was considered as a coordination disturbance.

By the end of the study period (28 days), rats in the three groups were sacrificed and brains were dissected for neurotransmitters assaying and histopathological examination.

\section{Neurotransmitters assaying in brain tissue:}

Sample Preparation:

The rats were sacrificed $24 \mathrm{~h}$ after the last dose of Voodoo extract. The brain was dissected out, $100 \mathrm{mg}$ of brain tissue of each rat was homogenized in 1 $\mathrm{ml}$ of phosphate buffer saline and stored overnight at $-20^{\circ} \mathrm{C}$.

\section{Serotonin:}

\section{Assay of}

Serotonin was assayed by a rat serotonin ELISA kit (LifeSpan BioSciences, LSBio Inc.), USA.

\section{Dopamine:}

Dopamine was assayed by an ELISA kit (Immuno-Biological Laboratories Inc.) USA.

\section{Adrenaline: \\ Assay of}

Adrenaline was assayed by a rat adrenaline ELISA kit (CUSABIO, Inc.), USA.

$$
\begin{gathered}
\bullet \quad \text { Assay } \\
\text { Noradrenaline: } \\
\text { Noradrenaline was assayed by a rat }
\end{gathered}
$$
noradrenaline ELISA kit (Eagle Biosciences, Inc.), USA.

\section{Histopathological examination of brain:}

The dissected brain was fixed in $10 \%$ formol saline and processed to prepare $5 \mu \mathrm{m}$ thick serial paraffin sections for haematoxylin \& eosin
(H\&E) staining to verify the histological details according to the method described by Wilson and Gamble, (2002).

\section{Immunohistochemical} reaction for caspase $\mathbf{- 3}$ :

Caspase- 3 was investigated using an ELISA kit (CUSABIO, Inc). USA.

\section{Statistical analysis:}

The collected data were computerized and statistically analyzed using SPSS for Windows statistical package, version 22. Quantitative data was expressed as mean and standard deviation (SD). ANOVA test was used to compare quantitative data in more than two groups and with Bonferroni post hoc test compare between groups. Student $t$ test was used to compare between two groups. Results considered to be significant when $p$ value $<0.05$ and highly significant when $\mathrm{p}$ value $<0.01$.

\section{RESULTS}

There were no statistical significant differences between -ve control group and +ve control groups as regard the tested parameters, so the -ve control group was chosen to express the results of the control group and to compare with the treated group.

\section{1- General Observation:}

The rats were hypoactive and not interested to food for 1 to 2 hours after giving the dose later, rats became hyperactive and aggressive.

\section{- $\quad$ Food intake:}

The results of food intake were presented in table (1) \& fig. (1). Mixed model ANOVA of the food intake showed significant overall effects of both groups $[F 2,27=120.1, P<0.001)]$ and time $[(F 2,60=152.4 ; P<0.001)]$, as well as a significant interaction between these two main factors $[F \quad 4,60=86$, $P<0.001)]$. Regarding Voodoo-treated rats, initial highly significant increase in food intake during the second week $(P=0.008)$ followed by a highly 
significant decrease in the third week $(P<0.001)$ then markedly increased in

the fourth week $(P=0.018)$.

Table (1): Comparison between -ve control group and Voodoo treated group as regard food intake, feces amount and body gain in adult male albino rats:

\begin{tabular}{|c|c|c|c|c|c|}
\hline \multirow{2}{*}{ Variables } & \multirow{2}{*}{ Groups } & \multicolumn{4}{|c|}{ Time } \\
\hline & & $1^{\text {st }}$ week & $2^{\text {nd }}$ week & $3^{\text {rd }}$ week & $4^{\text {th }}$ week \\
\hline \multirow{2}{*}{$\begin{array}{c}\text { Food intake } \\
(\mathrm{gm} / 100 \mathrm{gm} \mathrm{BW})\end{array}$} & -ve control & $12 \pm 0.67$ & $17.1 \pm 0.57$ & $17.3 \pm 0.82$ & $18 \pm 1.33$ \\
\hline & Voodoo treated & $13.5 \pm 0.97^{\mathrm{a}}$ & $14.9 \pm 0.32^{\mathrm{a}}$ & $10.2 \pm 0.63^{\mathrm{a}}$ & $12 \pm 0.82^{\mathrm{a}}$ \\
\hline \multirow{2}{*}{$\begin{array}{c}\text { Feces amount } \\
\text { (gm) }\end{array}$} & -ve control & $8 \pm 0.67$ & $14.1 \pm 0.74 \pm$ & $15.3 \pm 0.67$ & $17.7 \pm 0.48$ \\
\hline & Voodoo treated & $10 \pm 0.47^{\mathrm{a}}$ & $16 \pm 0.47^{\mathrm{a}}$ & $9.1 \pm 0.88^{\mathrm{a}}$ & $8.2 \pm 0.63^{\mathrm{a}}$ \\
\hline \multirow{2}{*}{$\begin{array}{c}\text { Body weight gain } \\
\text { (gm) }\end{array}$} & -ve control & $143.1 \pm 5.72$ & $166.5 \pm 6.69$ & $182.5 \pm 9.5$ & $202.2 \pm 7.12$ \\
\hline & Voodoo treated & $143.6 \pm 8.1^{\mathrm{a}}$ & $150 \pm 8.16^{\mathrm{a}}$ & $167 \pm 4.83^{\mathrm{a}}$ & $174.4 \pm 11.02^{\mathrm{a}}$ \\
\hline
\end{tabular}

All data were expressed as mean $\pm \mathrm{SD}$, significant if $\mathrm{P} \leq 0.05, \mathrm{a}=$ significant vs negative control group.

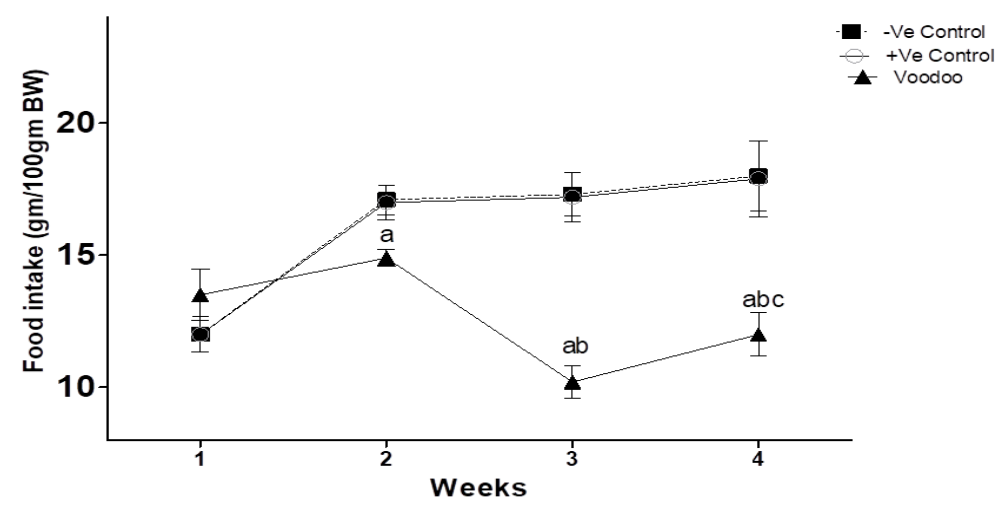

Figure (1): Effect of subchronic administration of Voodoo on food intake in rats. Food intake was assessed in 1, 2, 3 and 4 weeks after voodoo administration. Values are expressed as mean (SD). Repeated measure ANOVA with Bonferroni post hoc test (significant if $P \leq 0.05$ ), a significant vs first week-post treatment, b significant vs second week-post treatment, c highly significant vs third week-post treatment.

- Feces formation:

The results of feces amount were shown in table (1) \& fig. (2). Mixed model ANOVA of feces amount showed significant overall effects of both groups $\left.\left[\mathrm{F}_{2,27}=272.3, P=<0.001\right)\right]$ and time $\left[\left(\mathrm{F}_{2,65}=409.8 ; P<0.001\right)\right]$, as well as a significant interaction between these two main factors $\left[\mathrm{F}_{5,65}=191.5\right.$,
$P<0.001)]$. Regarding Voodoo-treated rats, initial highly significant increase in feces amount during the second week $(P<0.001)$ followed by a highly significant decrease in the third week $(P<0.001)$ then feces amount markedly decreased in the fourth week $(P<0.02)$. 


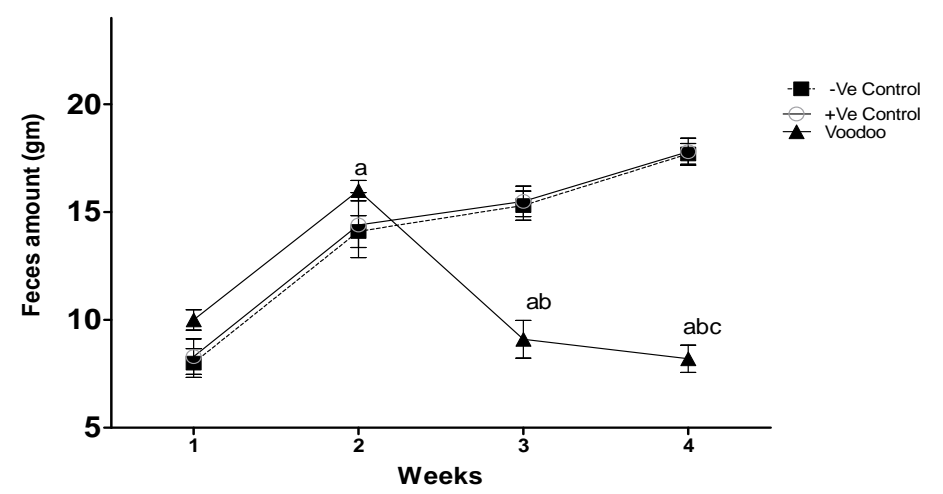

Figure (2): Effect of subchronic administration of Voodoo on feces amount in rats. It was assessed in the 4 weeks after voodoo administration. Values are expressed as mean (SD).

Repeated measure ANOVA with Bonferroni post hoc test (significant if $P \leq 0.05$ ), ${ }^{\text {a }}$ significant $v s$ first week-post treatment, ${ }^{\mathrm{b}}$ significant $v s$ second week-post treatment, ${ }^{\mathrm{c}}$ highly significant $v s$ third week-post treatment.

- Body weight gain:

The results of body weight gain were shown in table (1) \& fig. (3). Mixed model ANOVA of body weight gain showed significant overall effects of both groups $\left.\left[\mathrm{F}_{2,27}=36.7, P=<0.001\right)\right]$ and time $\left[\left(\mathrm{F}_{3}, 81=207.9 ; P<0.001\right)\right]$, as well as a significant interaction between these two main factors $\left[\mathrm{F}_{6,81}=5.6\right.$, $P<0.001)]$. Regarding voodoo-treated rats, initial highly significant increase in body weight gain during the second week $(P<0.001)$ followed by a highly significant decrease in the third week $(P=0.003)$ then body weight markedly decreased in the fourth week $(P<0.001)$.

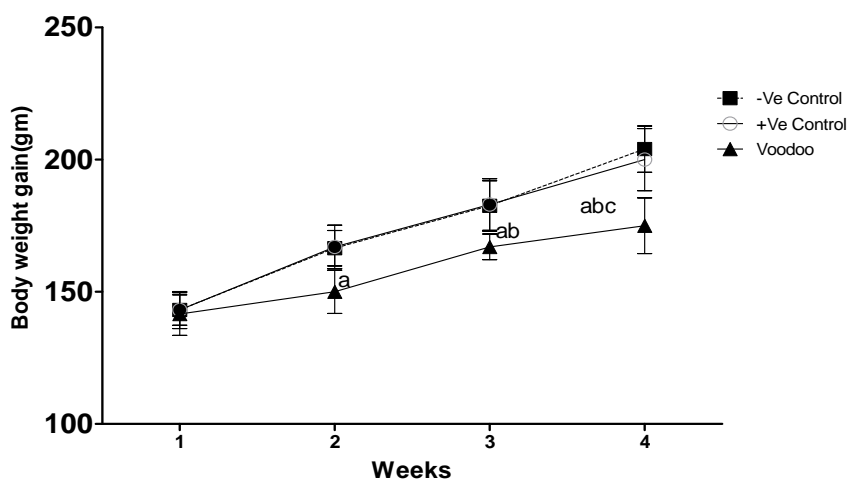

Figure (3): Effect of subchronic administration of Voodoo on body weight gain in rats. It was assessed in the 4 weeks after voodoo administration. Values are expressed as mean (SD).

Repeated measure ANOVA with Bonferroni post hoc test (significant if $\mathrm{P} \leq 0.05$ ), ${ }^{\text {a }}$ significant $v s$ first week-post treatment, ${ }^{\mathrm{b}}$ significant $v s$ second week-post treatment, ${ }^{\mathrm{c}}$ highly significant $v s$ third week-post treatment.

2- Behavioral tests results:

- Y maze spontaneous alternation test results:

During the 5-min session, the -ve control rats showed $80 \pm 5.0 \%$ spontaneous alternation while, Voodoo extract treated group showed approximately $43 \pm 4.5 \%$ spontaneous alternation. When the both groups were compared to each other a highly statistical significant inhibition of the spontaneous alternation was found $(\mathrm{t}$ test $=17.39, P<0.001)$.

\section{- Rotarod test results:}

During the 2-min session, 2 rats in the -ve control group were reported to fall down from the rotarod while, in 
Voodoo extract treated group there were 6 rats fell down. When the both groups were compared to each other a highly statistical significant inhibition of the coordinative function was reported ( $\mathrm{t}$ test $=56.56, p<0.001)$.

\section{3- Level of}

Neurotransmitters in brain issue results:

Means of the assayed Serotonin,

Table (2): Comparison between -ve control group and Voodoo treated group as regard the assayed neurotransmitters using student $t$ test:

\begin{tabular}{|c|c|c|c|c|c|}
\hline Variable & Groups & $\operatorname{mean} \pm \mathrm{SD}$ & t test & $P$ value & $95 \% \mathrm{CI}$ \\
\hline \multirow{2}{*}{$\begin{array}{c}\text { Serotonin } \\
(\mathrm{mg} / \mathrm{kg})\end{array}$} & -ve control & $0.713 \pm 0.015$ & \multirow{2}{*}{10.595} & \multirow{2}{*}{$\mathrm{P}<0.001$} & \multirow{2}{*}{$0.566-0.845$} \\
\hline & Voodoo treated & $0.0075 \pm 0.21$ & & & \\
\hline \multirow{2}{*}{$\begin{array}{c}\text { Dopamine } \\
(\mathrm{mg} / \mathrm{kg})\end{array}$} & -ve control & $1.126 \pm 0.024$ & \multirow{2}{*}{92.015} & \multirow[b]{2}{*}{$\mathrm{P}<0.001$} & \multirow{2}{*}{$1.09-1.14$} \\
\hline & Voodoo treated & $0.0081 \pm 0.03$ & & & \\
\hline \multirow{2}{*}{$\underset{(\mathrm{mg} / \mathrm{kg})}{\text { Adrenaline }}$} & -ve control & $0.623 \pm 0.12$ & \multirow{2}{*}{7.9035} & \multirow{2}{*}{$\mathrm{P}<0.001$} & \multirow{2}{*}{$0.443-0.765$} \\
\hline & Voodoo treated & $0.0185 \pm 0.21$ & & & \\
\hline \multirow{2}{*}{$\begin{array}{c}\text { Noradrenaline } \\
(\mathrm{mg} / \mathrm{kg})\end{array}$} & -ve control & $0.812 \pm 0.014$ & \multirow{2}{*}{21.2225} & \multirow{2}{*}{$\mathrm{P}<0.001$} & \multirow{2}{*}{$0.730-0.891$} \\
\hline & Voodoo treated & $0.0012 \pm 0.12$ & & & \\
\hline
\end{tabular}

All data were expressed as mean $\pm \mathrm{SD}$, significant if $\mathrm{P} \leq \mathbf{0 . 0 5} \mathrm{CI}=$ Confidence interval.

\section{4- Histopathological examination of the brain tissue:}

In the control group, the large pyramidal cells' cytoplasm was basophilic and contained large coarse basophilic granules and large, rounded, and central nucleus with prominent nucleolus as shown in fig. (4\&5).

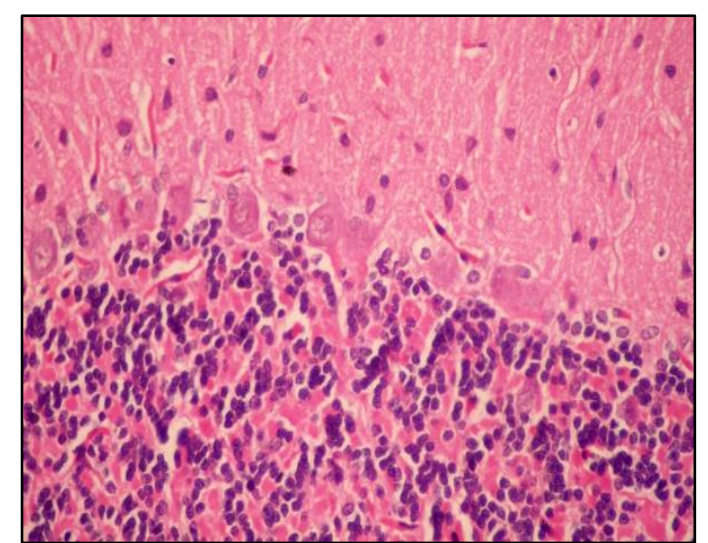

Figure (4): H\& E stained section in the brain of control group showing normal brain tissue architecture (H\&E stain X 200)
Dopamine, Adrenaline and Noradrenaline in both control group and Voodoo treated group were shown in table (2). A statistical significant inhibition of the assayed neurotransmitters was recorded in the Voodoo extract treated group when compared to the control group. 


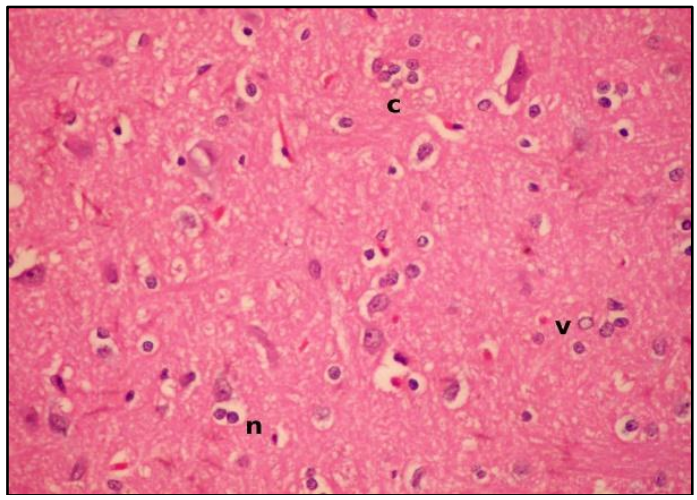

Figure (6): H\& E stained section in the brain of the treated group showing vacuolated neurons (c) some with darkly stained pyknotic nuclei (n) and others with vesicular nuclei (v) (H\&E stain X400).

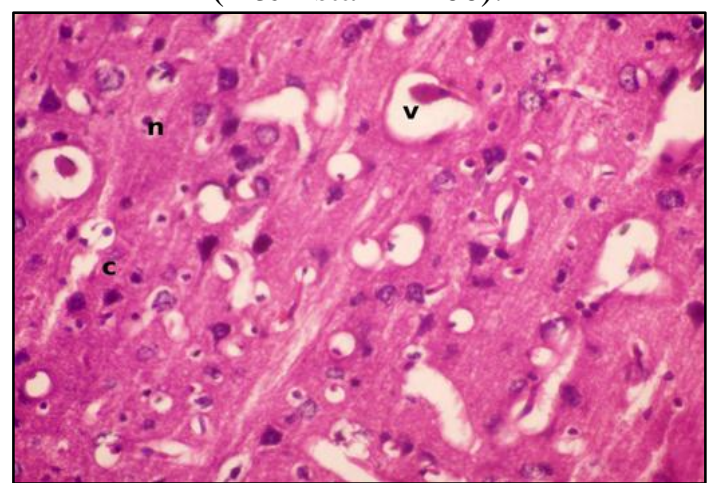

Figure (7): $\mathrm{H} \& \mathrm{E}$ stained section in the brain of group of the treated group showing increased number of affected neurons (c) with darkly stain nuclei (n) and marked vaculations (v) (H\&E stain X400).

The cells are surrounded by irregular wide spaces in addition to neuropill edema and hyalonosis (fig. 8\&9).

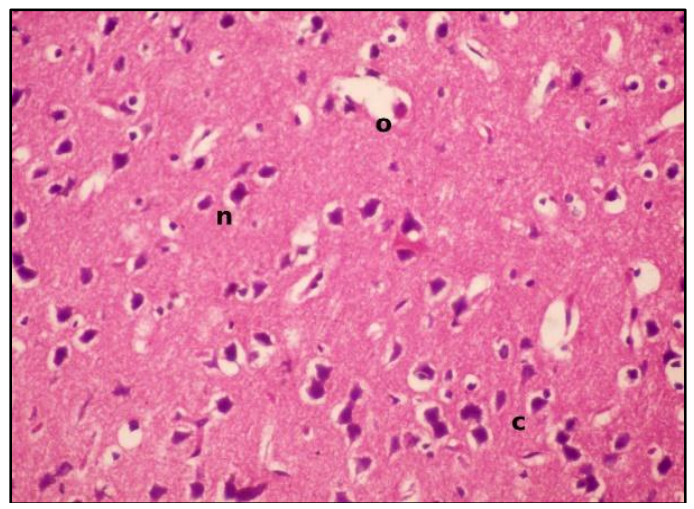

Figure (8): H\& E stained section in the brain of the treated group showing shrunken neurons (c) with pyknotic nuclei (n) and neuropil edema (o) (H\&E stain X400).

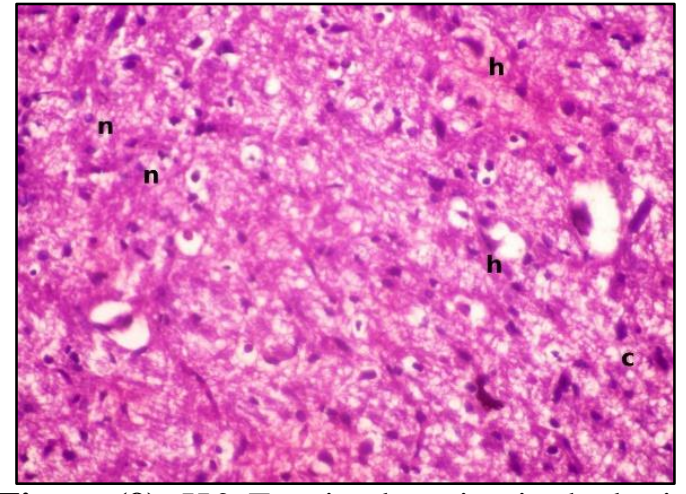

Figure (9): H\& E stained section in the brain of the treated group showing increased number of shrunken neurons (c) with darkly stain nuclei (n) and hyalonosis (h) (H\&E stain X400).

\section{5- Immunohistochemical reaction for caspase -3:}

Voodoo treated group showed strong positive cytoplasmic immunoreaction for caspase -3in the brain cells when compared to control group (fig. 10\&11).

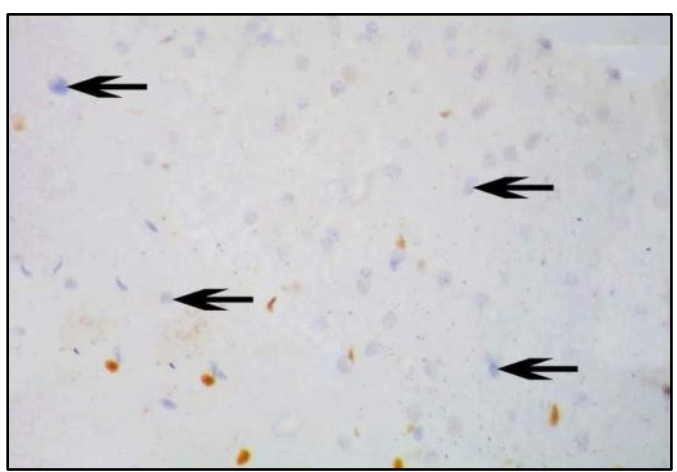

Figure (10): Immunohistochemical reaction for caspase -3 in the control group showing negative cytoplasmic immunoreaction for caspase -3 in the brain cells. (caspase - $\mathbf{3 x} \mathbf{4 0 0}$ )

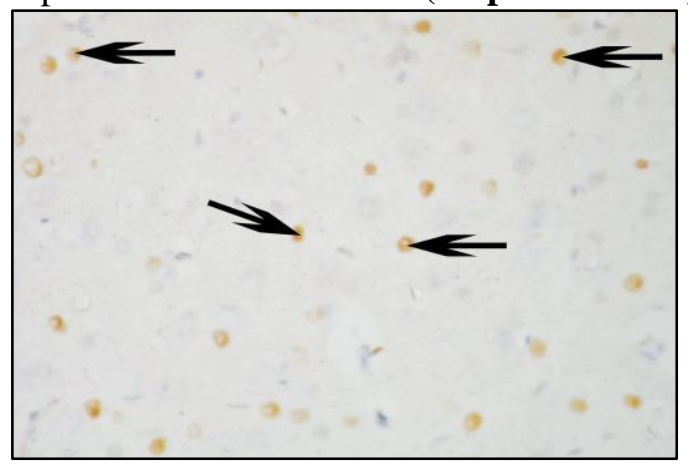

Figure (11): Immunohistochemical reaction for caspase -3 in the treated group showing strong positive cytoplasmic immunoreaction for caspase -3in the brain cells. (caspase - $\mathbf{3 x}$ 400). 


\section{DISCUSSION}

Synthetic cannabinoids (SCBs) have more potent and long lasting cannabis-like effects with difficult detection in urine due to the high variability of its constituents (Cha et al., 2015). Some of them were as much as 100-fold more potent than cannabis, as, PB-22 and 5F-PB-22 (Wiley et al., 2013). One of the biggest problems related to SCBs is the insufficient data related to their effects on human (Cha et al., 2015). Only a few case reports about the neurotoxicity produced by SCBs have been published (Harris and Brown, 2013). This study aimed to investigate the sub chronic neurotoxic effect of the newly emerged hallucinogenic substance "Voodoo" that appeared in the Egyptian market.

In the present study, general activity changes were reported between control and Voodoo treated group, in addition to a significant decrease in food intake, feces formation and weight gain. The behavioral Y maze test revealed significant inhibition of the spontaneous alternation which indicating learning and memory function defect and impaired cognition. Locomotor activity and rotarod test revealed significant inhibition of the neuromuscular coordinative function. The neurotransmitters (Adrenaline, Noradrenaline, Dopamine and Serotonin) analysis in brain tissue of the Voodoo treated group revealed significant inhibition of these neurotransmitters. These neurological changes were supported by the histopathological findings and the positive cytoplasmic immunoreaction for caspase -3 in the brain tissues. These results are consistent with Cha et al. (2015) who evaluated the neurotoxic effect of two SCBs given in different doses $(0.1,1,5 \mathrm{mg} / \mathrm{kg})$ to mice, they reported tractions, tremors, decreased locomotor activities and rotarod retention time in addition to the histopathological neuro-modulatory system in the CNS (Noradrenergic, Serotonergic and findings in nucleus accumbens and concluded that the SCBs might be neurotoxic through neuronal cell damages. Furthermore, Abbas et al. (2017) who studied the acute toxic effect of Voodoo both clinical and experimental, stated that experimental study through histopathological examination of tissues from different organs in rats revealed that the brain was the most affected organ. Compton et al., (2012) investigated the SCBs' effects on neuropsychology, development and behavior of adult rats and claimed that chronic exposure to SCBs during adolescence might affect spatial learning and memory performance in adulthood. These changes can be explained by the adaptive changes occurs in the $\mathrm{CB} 1$ receptors and the related neurotransmitters that result in severe behavioral adverse effects (Basavarajappa \& Subbanna 2019). This is supported by the findings reported by Atwood et al., 2010 in which SCBs' reduced the excitatory postsynaptic currents levels in cultured hippocampal neurons. In the same way Cottencin et al., (2014) claimed that chronic use of SCBs (Spice) may induce significant deterioration in emotional and cognitive function because SCBs have important effects on emotional processing and sensory perception. The negative effects of cannabinoids' agonists on learning ability and memory are well documented, this might be explained by their activity at CB1 receptors which are present at high concentration in the hippocampus and prefrontal cortex, as well as other forebrain areas (Schreiber et al., 2018).

Although it is more convenient to limit experiments with SCBs to the endocannabinoid system and the intracellular signaling, there is a growing evidence suggesting an interaction between SCBs and the

Dopaminergic systems) that has significant functional and behavioral 
effect (Fantegrossi et al., 2018 \& Sara, 2009).

Cannabinoids are found to be involved in many neurotransmitter release suppression as $\gamma$-aminobutyric acid (GABA), Dopamine, Histamine, Serotonin, Norepinephrine and Opioids (Piomelli, 2003). So, cannabinoids are claimed to modulate the main excitatory and inhibitory systems of the CNS which in turn affecting; food intake and metabolism (Viveros et al., 2008), the response to chronic stress (Hill et al., 2005) and enhancing neuropsychiatric disorders (Hill and Gorzalka, 2009). Braida et al. (2007) reported the modulatory effect of Cannabinoids on the Serotonergic system not only by direct activation of CB1 receptors but also by its direct effect on its receptor expression in chronic abuse. Furthermore, Bloomfield et al. (2014) reported a reduced Dopamine synthesis capacity in the striatum in chronic Cannabinoids use. Urbanan et al. (2012) stated that mild to moderate dependence on $\mathrm{CB} 1$ receptors do not affect the striatal Dopamine alterations while, longer duration of use reduced the Dopamine release. In the same way, Cannabinoids were found to modulate Noradrenergic transmission not only in Noradrenergic nuclei but also at the target regions, in addition, Norepinephrine was found to mediate some behaviors induced by cannabinoids (Carvalho and Van Bockstaele, 2012). In the present study, an activation of apoptotic chain in the brain tissues was found after treatment with Voodoo extract which was evidenced by significant increase in caspase-3 presentations. This was consistent with Basavarajappa and Subbanna (2019) who reported cytotoxic effects induced by SCBs in vitro studies. Tomiyama and Funada (2011) found that, caspase cascades might have a significant role in the apoptosis induced by SCBs and added that this cytotoxicity was caspase- 3 and CB1-dependent.

Furthermore,
Zehendner et al. (2011) stated that caspase-3 which is a crucial mediator of programmed cell death (apoptosis), played a very important role in the apoptosis induced by many neurotoxins leading to various neurodegenerative disorder.

\section{CONCLUSION}

From the results of this study we can conclude that, Voodoo extract was found to had a functional and structural deleterious CNS effect with sub chronic exposure in male albino rats in the form of learning and memory function defects, impaired cognition, inhibition of the neuromuscular coordinative function and inhibition of the neurotransmitters; Serotonin, Dopamine Adrenaline, and Noradrenaline. These neurological changes were supported by the histopathological findings in the form of irregular shrunken cells with dense nuclei and vacuolated cytoplasm in addition to the positive cytoplasmic immunoreaction for caspase -3 in the brain tissue.

\section{RECOMMENDATIONS}

The studies on the acute SCBs effect are available, but there are insufficient studies on the chronic abuse of them. There is a lack about the degree to which the brain development and functions are affected especially in youngs who have been shown to develop an increased risk of SCBs dependence. So, further studies are recommended to evaluate the toxic effects of these compounds on the different body tissues in case of chronic abuse conditions especially on CNS in young users.

\section{REFERENCES}

Abbas, M.A.; Hassan, M.Z.M.; Abd Elhaleem, M.R., AbdElaziz, H.R. and AbdAllah, R.H. (2017): Acute Toxicity of a Novel Class of Hallucinogen "Voodoo" (Clinical and Experimental Study). Ain Shams 
Journal of Forensic Medicine and Clinical Toxicology, 28: 62-73.

Akutsu, M. (2017): Analysis of 62 synthetic cannabinoids by gas chromatography-mass spectrometry with photoionization. Forensic Toxicol.,35(1):94-103.

Atwood, B.K.; Huffman, J.; Straiker, A. and Mackie, K. (2010): Jwh018, a common constituent of 'spice' herbal blends, is a potent and e_cacious cannabinoid cb receptor agonist. Br. J. Pharmacol., 160(3): 585-593.

Basavarajappa, B. S. and Subbanna, S. (2019): Potential Mechanisms Underlying the Deleterious Effects of Synthetic Cannabinoids Found in Spice/K2 Products. Brain Sci., 9(1): 14.

Bloomfield, M.A.P.; Morgan, C.J.A.; Egerton, A.; Kapur, S.; Curran, H.V.; Howes, O.D. (2014): Dopaminergic function in cannabis users and its relationship to cannabisinduced psychotic symptoms. Biol Psychiatry, 75:

470-478.

Braida, D.; Limonta, V.; Malabarba, L.; Zani, A. and Sala, M. (2007): 5HT1A receptors are involved in the anxiolytic effect of $\Delta 9$ tetrahydrocannabinol and AM 404, the anandamide transport inhibitor, in Sprague-Dawley rats. Eur $\mathbf{J}$ Pharmacol, 555:156-63.

Carvalho, A.F. and Van Bockstaele, E.J. (2012): Cannabinoid modulation of noradrenergic circuits: implications for psychiatric disorders. Prog Neuropsychopharmacol Biol Psychiatry.; 38(1): 59-67.

Cha, H. J.; Seong, Y. H.; Song M.J.; Jeong H.S.; Shin J.;Yun J. et al. (2015): Neurotoxicity of Synthetic Cannabinoids JWH-081 and JWH210. Biomol Ther, 23(6): 597-603.
Chopra, S.; Soni, R. and Chopra, A.A. (2000): computer program for determination of LD50 using Dbase/Foxpro. Indian Journal of Pharmacology, 32: 390-391.

Compton, D.M.; Seeds, M.; Pottash, G.; Gradwohl, B.; Welton, C. and Davids, R. (2012): Adolescent exposure of jwh-018 "spice" produces subtle e_ects on learning and memory performance in adulthood. J. Behav. Brain Sci., 2(2), 146-155.

Cottencin, O.; Rolland, B. and Karila L. (2014): New Designer Drugs (Synthetic Cannabinoids and Synthetic Cathinones): Review of Literature. Current Pharmaceutical Design, 20(25):4106-11.

Dunham, N.W. and Miya T.A. (1957): note on a simple apparatus for detecting neurological deficit in rats and mice. J Am Pharm Assoc Am Pharm Assoc., 46(3):208-9.

Egypt drug regulatory authority (2014): available from www.ginad.org/en/info. Published 9 December, 2014.

Every-Palmer, S. (2010): Warning: legal synthetic cannabinoid-receptor agonists such as JWH- 018 may precipitate psychosis in vulnerable individuals. Addiction, 105: 185960.

Faizi, M.; Bader, P. L.; Saw, N.; Nguyen, V. T; Beraki, S.; WyssCoray, T.; et al. (2012): Thy1hAPPLond/Swe+ mouse model of Alzheimer's disease displays broad behavioral deficits in sensorimotor, cognitive and social function. Brain and Behavior, 2(2): Pages 142-154.

Fantegrossi, W. E.; Wilson, C.D. and Berquist M. D. (2018): Propsychotic effects of synthetic cannabinoids: interactions with central dopamine, serotonin and glutamate systems. Drug Metab Rev.50(1): 65-73. 
Guxens, M.; Nebot, M.; Ariza, C. and Ochoa, D. (2007): Factors associated with the onset of cannabis use: a systematic review of cohort studies. Gac Saint, 21: 252-260.

Gad S \& Weil C. (1989): Statistics for toxicologists. In Hayes A (ed.) Principles and methods of toxicology. 2nd ed. Chap. 15. New York: Raven Press, , p.435-479.

Harris, C.R. and Brown, A. (2013): Synthetic Cannabinoid Intoxication: A Case Series and Review. The Journal of Emergency Medicine, 44, 360-366.

Hill, M.N. and Gorzalka, B.B. (2009): The endocannabinoid system and the treatment of mood and anxiety disorders. CNS Neurol Disord Drug Targets, 8(6):451-8.

Huestis, M. (2002): Cannabis effects on human behavior and performance. $\mathbf{J}$ Forensic Sci Rev,14: 1-25.

Johnston, LD.; O'Malley, PM.; Bachman, JG. and Schulenberg, JE. (2011): Marijuana use continues to rise among US teens, while alcohol use hits historic lows. Ann Arbor, MI: University of Michigan News Service. at http://www.monitoringthefuture.org

Kearney-Ramos, T. E.; Tai, S.; Brents, L. K. and Prather P.L. (2014): In vivo effects of synthetic cannabinoids JWH-018 and JWH073 and phytocannabinoid $\triangle 9$-THC in mice: Inhalation versus intraperitoneal injection. Pharmacol Biochem Behav, 124: 40-47.

Kevin, R.C., Wood, K.E., Stuart, J., Mitchell, A.J., Moir, M., Banister, S.D. et al. (2017): Acute and residual effects in adolescent rats resulting from exposure to the novel synthetic cannabinoids AB-PINACA and AB-FUBINACA. J. Psychopharmacol., 31(6):757-769.

Miller, L.C. and Tainter, M.L. (1944): Estimation of LD50 and its error by means of log-probit graph paper.
Proc. Soc. Exp. Biol. Med., 57:261264.

Obata, Y. and Ishikawa Y. (1960): Studies on the Constituents of Hemp Plant (Cannabis sativa L.). Bull. Agri. Chem. Soc. Japan, 24(7): 667669.

Piomelli D. (2003): The molecular logic of endocannabinoid signalling. Nat Rev Neurosci, 4:873-84.

Sara. S.J. (2009): The locus coeruleus and noradrenergic modulation of cognition. Nat Rev Neurosci. 10:211223.

Schneir, A.B; Cullen. J. and Ly, B.T. (2011): "Spice" girls: synthetic cannabinoid intoxication. J. Emerg. Med., 40: 296-299.

Schreiber, S.; Bader, M.; Lenchinski, T.; Meningher, I.; Rubovitch, V.; Katz, Y.; et al. (2018): Functional effects of synthetic cannabinoids versus $\triangle 9$-THC in mice on body temperature, nociceptive threshold, anxiety, cognition, locomotor/exploratory parameters and depression. Addiction Biology, 24, 414-425.

Svízenská, I.; Dubovy, P. and Sulcová, A. (2008): Cannabinoid receptors 1 and 2 (CB1 andCB2), their distribution, ligands and functional involvement in nervous system structures - A short review. Pharmacol. Biochem. Behav., 90(4):501-511.

Tims, F.M.; Dennis, M.L. and Hamilton, N. (2002): Characteristics and problems of 600 adolescent cannabis abusers in outpatient treatment. Addiction, 97 (1): 46-57.

Tomiyama, K. and Funada, M. (2011): Cytotoxicity of synthetic cannabinoids found in "spice" products: The role of cannabinoid receptors and the caspase cascade in the ng 108-15 cell line. Toxicol. Lett., 207, 12-17.

Urbanan, N. B.L.; Slifsteina, M.; Thompsona, J. L.; Xua, X.; 
Girgisa, R. R.; Raheja, S. et al. (2012): Dopamine Release in Chronic Cannabis Users: A [11C] Raclopride Positron Emission Tomography Study. Biological Psychiatry, 71(8): 677-683.

Vandrey, R.; Dunn, K.E.; Fry, J.A. and Girling E.R. (2012): A survey study to characterize use of Spice products (synthetic cannabinoids). Drug Alcohol Depend, 120(1-3):23841.

Vardakou, I.; Pistos, C. and Spiliopoulou, C.H. (2010): Spice drugs as a new trend: mode of action, identification and legislation. Toxicol Lett.; 197(3):157-62.

Viveros, M.P.; de Fonseca, F.R.; Bermudez-Silva, F.J.; and McPartland, J.M. (2008): Critical role of the endocannabinoid system in the regulation of food intake and energy metabolism, with phylogenetic, developmental, and pathophysiological implications. Endocr Metab Immune Disord Drug Targets, 8:220-30.

Wiley, J.L., Marusich, J.A. and Lefever, T.W. (2013): Cannabinoids in disguise: $\Delta 9$ tetrahydrocannabinol-like effects of tetramethylcyclopropyl ketone indoles. Neuropharma., 75:145-154.

Wilson, I. and Gamble, M. (2002): The hematoxylin and eosins, In: Theory and Practice of Histological Techniques. Bancroft JD and Gamble M. (eds.) 5th ed., Churchill Livingstone. Elservier Science Limited, London, UK, pp: 125-138.

Yamada, K.; Noda, Y.; Hasegawa, T.; Komori, Y.; Nikai, T.; Sugihara H.; et al. (1996): The role of nitric oxide in dizocilpine-induced impairment of spontaneous alternation behavior in mice. $\mathrm{J}$. Pharmac. exp. Ther, 276, 460-466.

Yassa, H. A.; Dawood, A. A. and Shehata, M. M. (2010): Subchronic toxicity of cannabis leaves on male albino rats. Hum. Exp. Toxicol., 29(1): 37-47.

Zehendner, C.M.; Librizzi, L.; de Curtis, M.; Kuhlmann, C.R.W. and Luhmann, HJ (2011): Caspase3 contributes to ZO-1 and Cl-5 tightjunction disruption in rapid anoxic neurovascular unit damage. PloS One [electronic resource], 6: e16760.

Zimmermann, U.S.; Winkelmann, P.R. and Pilhatsch, M. (2009): Withdrawal phenomena and dependence syndrome after the consumption of "spice gold." Dtsch. Arztebl. Int., 106: 464-67. 


\section{الملخص العربي}

التأثير السمي المزمن لمستخرج الفودو على الجهاز العصبي المركزي في ذكور الجرذان

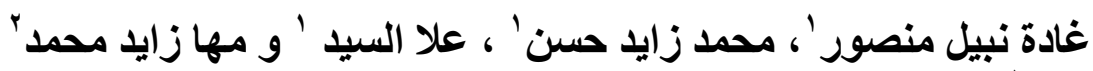

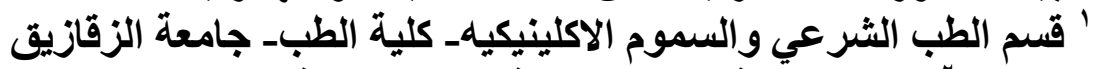

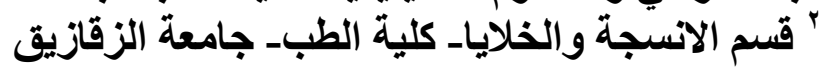

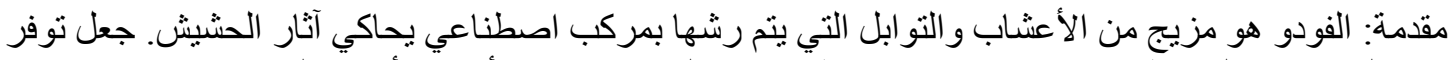

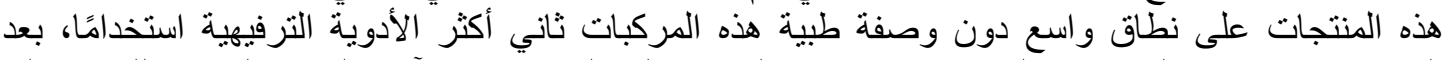

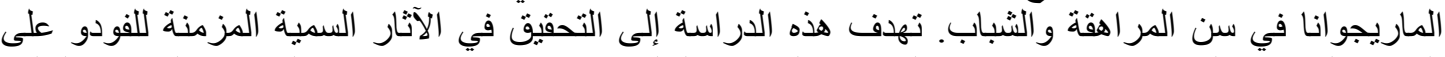

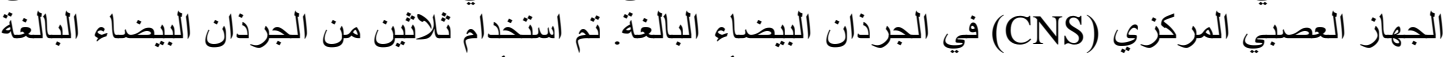

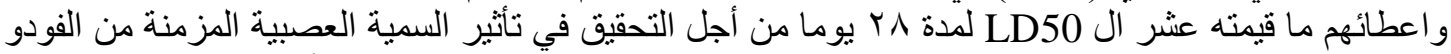

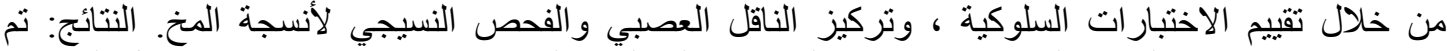

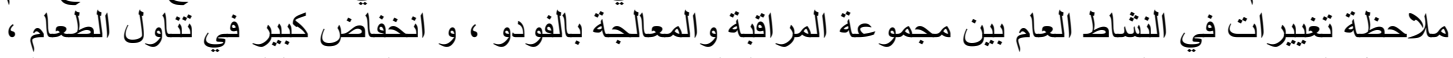

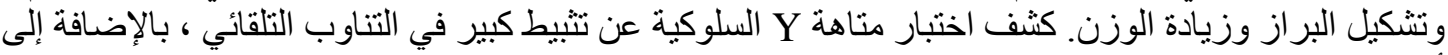

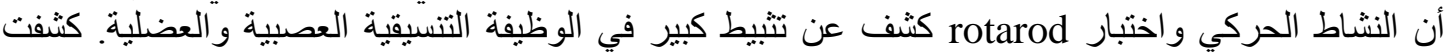

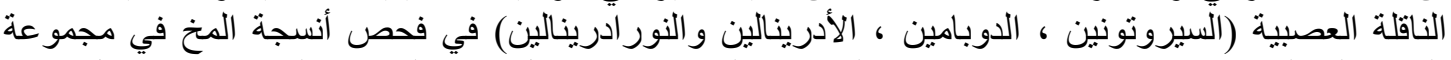

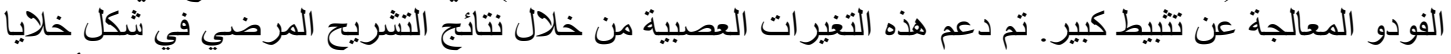

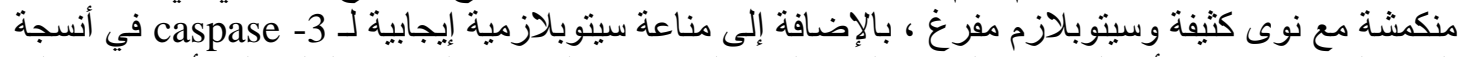

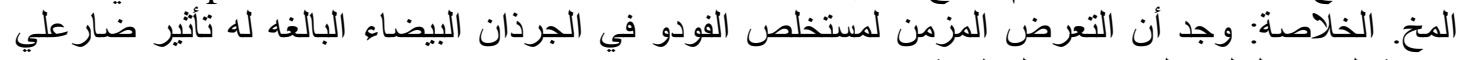
انسجة المخ وبالتالي علي كفاءته الوظيفية . 